\title{
ZnO Nano-Flower Deposition on Top of Rectifying Metal- Semiconductor Contacts Towards an Active Structure Formation
}

\author{
G.X. Glenis, I.P. Stathopoulos, T.G. Argyropoulos and C.T. Dervos* \\ National Technical University of Athens, School of Electrical and Computer Engineering, Laboratory \\ of Electrical Materials. \\ "E-mail: cdervos@ central.ntua.gr
}

doi: $10.20964 / 2017.07 .11$

Received: 6 February 2017 / Accepted: 25 April 2017 / Published: 12 June 2017

\begin{abstract}
Rectifying metal-semiconductor contacts of zinc blende (111) CdSe films were electrolytically grown on pure $\mathrm{Ni}$ substrates. ZnO nano-flowers (grown hydrothermally) were deposited on top of the CdSe layer by spin-on coating, and by casting technique. The 3D morphology and overall structure of the $\mathrm{Ni} / \mathrm{CdSe} / \mathrm{ZnO}$ specimens were characterized by XRD, SEM, EDAX and optical measurements of energy gap. The electrical properties of the investigated material structures were determined by measuring $\mathrm{I}-\mathrm{V}$ characteristics of $\mathrm{Ni} / \mathrm{CdSe} / \mathrm{Au}$, and $\mathrm{Ni} / \mathrm{CdSe} / \mathrm{ZnO}$ nano-flowers/Au structures, in the dark and following vacuum dehydration. According to the experimental results the incorporation of $\mathrm{ZnO}$ nano-flowers provides electrically active structures, possibly due to ongoing atmospheric ion neutralization processes. Thus, the deposition of $\mathrm{ZnO}$ nano-flowers may be practically utilized on top of photovoltaic (PV) semiconductor cells to offer: enhanced conversion efficiencies, protection of underlying semiconductor layers against UV-photons, and elimination of surface recombination of electronic carriers by exploiting the energy gap variations across the interconnected materials to push away the minority carriers.
\end{abstract}

Keywords: $\mathrm{ZnO}$ nano-flowers, $\mathrm{CdSe}$ electrodeposition, $\mathrm{ZnO} / \mathrm{CdSe}$ contacts, active structures, energy harvesting.

\section{$\underline{\text { FULL TEXT }}$}

(C) 2017 The Authors. Published by ESG (www.electrochemsci.org). This article is an open access article distributed under the terms and conditions of the Creative Commons Attribution license (http://creativecommons.org/licenses/by/4.0/). 